\title{
Innovation and Leadership in Public Sector Organizations
}

\author{
Mahmoud Moussa \\ PhD Candidate in Management and Sessional Lecturer, College of Business \\ School of Management at RMIT University, Melbourne, Australia \\ E-mail:mahmoud.moussa@rmit.edu.au \\ Professor Adela McMurray \\ Director, College of Business, School of Management \\ Doctoral Training Centre at RMIT University, Melbourne, Australia \\ E-mail: adela.mcmurray@rmit.edu.au \\ Dr. Nuttawuth Muenjohn \\ Senior Lecturer, College of Business \\ School of Management at RMIT University, Melbourne, Australia \\ E-mail: nuttawuth.muenjohn@rmit.edu.au
}

Received: April 2, 2018 Accepted: May 24, $2018 \quad$ Published: July 1, 2018

doi:10.5296/jmr.v10i3.13101ＵRL: https://doi.org/10.5296/jmr.v10i3.13101

\begin{abstract}
Although studies have addressed the factors that affect innovation, the findings have often been unclear and inconclusive. This is because there is no consistent definition of the concept of innovation in the existing literature. In addition, leadership behaviors that promote innovation in the public sector differ considerably from one nation to another. Thus, this study presents a consolidated in-depth literature review and analysis of the innovation and leadership literature that is specific to public sector organizations across nations. The analysis informs the development of a workplace innovation conceptual model specific to the public sector. The findings increase our understanding of how to effectively define innovation and to recognize the way in which leadership behaviors enhance public sector cultures of innovation.
\end{abstract}

Keywords: innovation, organization, public sector, leadership 
Although innovation research has increased over several decades in the United States and Europe, few studies were developed in the Asia Pacific region, particularly in Australia. Like all critical concepts, innovation has and will have different interpretations, and paradigms. This leads to different definitions and measurement tools within and across nations. Factors that stimulate or hinder innovation in the public sector across nations require careful attention for a variety of reasons. It is apparent that practitioners and scholars are not on the same page regarding public sector innovation research. That is expected because it is still an emergent field and lessons are drawn from a plethora of perspectives (Potts \&Kastelle, 2010; Stewart-Weeks \& Kastelle, 2015).

Innovation in the public sector has long been criticized for its failure to fulfil expectations of higher efficiency and better service. Bartos (2003) argued that innovation weighs high risks for both ministers and bureaucrats because if novel perspectives in policies or administration are adopted and fail, they will draw criticism. Bartos envisaged that reasons behind the adoption of new directions are due to the following: rational ideas with credibility, political support for specific trends, bureaucratic capacity and little resistance to change, strong commitment for innovation at both the political and bureaucratic levels, and strong need for change that cannot be neglected due to either political imperatives or national benefits. Similarly, Lekhi (2007) acknowledged reasons to innovate in the public sector, due to: (a) pressures over public institutions for the quality for their service, and their levels of efficiency; (b) governments' tendency to build a public image that enhances international appeal and attract private investments; and (c) governments must demand votes, and/or have the potential to fulfill policy commitments or show their efforts in the public sector as a result of an election or perceived shifts in public perceptions. Nonetheless, innovative organizations are the output of the following three prerequisites: (1) management capability of handling innovation, and employee involvement programs; (2) organizational culture that allows interpretations as a response to disturbances and changes occurred; and (3) collective, organized, and prioritized workplace (Jensen, 2010).

The objective of this paper is to critically review academic publications in innovation and leadership in public sector organizations in leading nations around the globe. The paper is conducted to gain a better understanding of how to effectively define innovation and to identify leadership behaviors that promote a culture of innovation in public sector organizations. In this international literature review, the authors limited their search strategy to present journal articles published between 2000 and 2017. The selected journals publish either empirical research or literature reviews regarding innovation and leadership in public sector organizations.

\section{Innovation in the Public Sector in Leading Countries}

Nowadays, public sector organizations around the globe consider the development of new ideas and innovation paramount and inevitable, due to the intense global competition and the rapid technological development. Luke, Verreynne, and Kearins (2010) conducted three cases in New Zealand and revealed that drivers and facilitators of innovative and entrepreneurial activity in the public sector are associated with risk acceptance, pro-activeness, and growth. 


\section{Macrothink}

However, other external elements were related to performance such as operational excellence and cost efficiency.

Other internal elements include a more flexible environment, investment in people, an emphasis on branding, and knowledge transfer among individuals in organizations. $\mathrm{Wu}, \mathrm{Ma}$, and Yang (2013) described and analyzed the state of the art in public sector innovation in China, with an emphasis on its types and distribution. Their findings showed the major types of innovation in public sector organizations in China to be management, service, and collaborative innovation; though, technological and governance innovation are thriving. Dumay, Rooney, and Marini (2013) examined cross-sectional empirical data collected from semi-structure interviews with 27 Australian executives in leading Australian enterprises and the public sector. Their findings illustrated how senior managers are liable for allowing and resourcing innovation and need to develop competencies required to recognize the innovation type enabled and match it to a relevant strategic approach.

Chesbrough, Vanhaverbeke, Bakici, and Lopez (2011) offered a charter for open innovation policies in Europe, as presented: education and human capital development, financing open innovation, adopt a balanced approach to intellectual property, enhanced cooperation and competition, and increased open government. O'Byrne, Miller, Douse, Venkatesh, and Kapucu (2014) conducted reviews through scholarly literatures and the findings indicated many instances of social innovation across the Seoul Metropolitan Government (SMG) which was presented in four sections and its constituents, as follows: motivation; culture; collaboration; and sustainability. The authors suggested that there are several innovations within the SMG that other metropolitan governments may consider when considering social innovations as a governance tool. The authors also indicated that Seoul continue to collaborate across sectors and most importantly, sustaining innovation will be done through policies for sustainability and governance capacity to foster and support new ideas.

Bakke and Nielsen (2014) attempted to investigate how managers perceive and measure innovation in the Norwegian public sector and concluded significant matters. These were: (a) managers' lack of understanding of innovation, which made it necessary to establish a common definition or explanation of the concept for the public sector; (b) managers face a lot of complexity, regarding issues such as novelty, degree of change necessary, and the execution phase, when communicating what comprises innovation; (c) managerial roles and responsibilities regarding innovation were comprehended differently across public sector organizations; and (d) innovation capacity was found correlated with the ability to adapt to a changing environment. 


\section{Macrothink}

Journal of Management Research

ISSN 1941-899X 2018, Vol. 10, No. 3

Table 1. The Top 25 Global Innovators: Government in 2016

\begin{tabular}{|c|c|c|}
\hline Organization & Country/Region & Rank \\
\hline CEA & France & 1 \\
\hline FraunhoferGesellschaft & Germany & 2 \\
\hline Japan Science \& Technology Agency (JST) & Japan & 3 \\
\hline Department of Health and Human Services (HHS) & US & 4 \\
\hline Centre National de la RechercheScientifique (CNRS) & France & 5 \\
\hline Korea Institute of Science \& Technology & South Korea & 6 \\
\hline National Institute of Advanced Industrial Science \& Technology (AIST) & Japan & 7 \\
\hline United States Department of Energy (DOE) & US & 8 \\
\hline Agency for Science Technology \& Research (ASTAR) & Singapore & 9 \\
\hline Institut National de la Sante et de la RechercheMedicale (Inserm) & France & 10 \\
\hline Helmholtz Association & Germany & 11 \\
\hline US Department of Veteran Affairs & US & 12 \\
\hline RIKEN & Japan & 13 \\
\hline National Research Council Canada & Canada & 14 \\
\hline Max Planck Society & Germany & 15 \\
\hline Chinese Academy of Sciences & China (Mainland) & 16 \\
\hline Le Reseau International des Instituts Pasteur (RIIP) & France & 17 \\
\hline National Institute of Materials Science (NIMS) & Japan & 18 \\
\hline US Navy & US & 19 \\
\hline Commonwealth Scientific \& Industrial Research Organization (CSIRO) & Australia & 20 \\
\hline Consejo Superior de InvestigacionesCientificas (CSIC) & Spain & 21 \\
\hline Academia Sinica & Taiwan & 22 \\
\hline US Army & US & 23 \\
\hline National Aeronautics \& Space Administration (NASA) & US & 24 \\
\hline Russian Academy of Sciences & Russia & 25 \\
\hline
\end{tabular}

Source: Adopted from Thomson Reuters Derwent World Patents Index, In Cites and Web of Science. 
Thirty-two percent of the top 25 organizations are from Europe, four of which are from France, three from Germany and one from Spain. Asia has eight top 25 global government innovators, four from Japan, and one each from China (mainland), Singapore, South Korea, and Taiwan. There are seven from North America, all of which are from the US except one from Canada, and one each from Australia and Russia. While the United States has 24 percent (or six) of the world's most innovative government in the top 25, as shown in Table 1, France is the leader in the top 10, with 30 percent (three) of the top ten slots. Japan and the US each has 20 percent (two) such organizations in the top 10.

Table 2. Global Innovation Indices (GII) in 2014-2017

\begin{tabular}{|c|c|c|c|c|c|c|c|c|c|c|c|c|c|c|c|c|c|c|c|c|}
\hline \multirow{2}{*}{$\begin{array}{l}\text { Country/ } \\
\text { Economy }\end{array}$} & \multicolumn{4}{|c|}{ Score $(0-100)$} & \multicolumn{4}{|c|}{ Rank } & \multicolumn{4}{|c|}{ Income } & \multicolumn{4}{|c|}{ Region } & \multicolumn{4}{|c|}{ Efficiency Ratio } \\
\hline & 2014 & 2015 & 2016 & 2017 & 2014 & 2015 & 2016 & 2017 & 2014 & 2015 & 2016 & 2017 & 2014 & 2015 & 2016 & 2017 & 2014 & 2015 & 2016 & 2017 \\
\hline Australia & 55.01 & 55.22 & 53.07 & 51.83 & 17 & 17 & 19 & 23 & $\mathrm{HI}$ & $\mathrm{HI}$ & $\mathrm{HI}$ & $\mathrm{HI}$ & SEAO & SEAO & SEAO & SEAO & 0.70 & 0.70 & 0.64 & 0.60 \\
\hline $\begin{array}{l}\text { New } \\
\text { Zealand }\end{array}$ & 54.52 & 55.92 & 54.23 & 52.87 & 18 & 15 & 17 & 21 & HI & HI & $\mathrm{HI}$ & $\mathrm{HI}$ & SEAO & SEAO & SEAO & SEAO & 0.75 & 0.77 & 0.73 & 0.65 \\
\hline Canada & 56.13 & 55.73 & 54.71 & 53.65 & 12 & 16 & 15 & 18 & HI & HI & HI & $\mathrm{HI}$ & NAC & NAC & NAC & NAC & 0.69 & 0.71 & 0.67 & 0.64 \\
\hline $\begin{array}{l}\text { South } \\
\text { Korea }\end{array}$ & 55.27 & 56.26 & 57.15 & 57.70 & 16 & 14 & 11 & 11 & $\mathrm{HI}$ & $\mathrm{HI}$ & $\mathrm{HI}$ & $\mathrm{HI}$ & SEAO & SEAO & SEAO & SEAO & 0.78 & 0.80 & 0.80 & 0.82 \\
\hline U.S.A. & 60.09 & 60.10 & 61.40 & 61.40 & 6 & 5 & 4 & 4 & HI & HI & $\mathrm{HI}$ & $\mathrm{HI}$ & NAC & NAC & NAC & NAC & 0.77 & 0.79 & 0.79 & 0.78 \\
\hline UK & 62.37 & 62.42 & 61.93 & 60.89 & 2 & 2 & 3 & 5 & $\mathrm{HI}$ & $\mathrm{HI}$ & $\mathrm{HI}$ & $\mathrm{HI}$ & EUR & EUR & EUR & EUR & 0.83 & 0.86 & 0.83 & 0.78 \\
\hline Belgium & 51.69 & 50.91 & 51.97 & 49.85 & 23 & 25 & 23 & 27 & $\mathrm{HI}$ & $\mathrm{HI}$ & $\mathrm{HI}$ & $\mathrm{HI}$ & EUR & EUR & EUR & EUR & 0.78 & 0.74 & 0.78 & 0.67 \\
\hline $\begin{array}{l}\text { The } \\
\text { Netherlands }\end{array}$ & 60.59 & 61.58 & 58.29 & 63.36 & 5 & 4 & 9 & 3 & $\mathrm{HI}$ & $\mathrm{HI}$ & $\mathrm{HI}$ & $\mathrm{HI}$ & EUR & EUR & EUR & EUR & 0.91 & 0.92 & 0.82 & 0.93 \\
\hline Hong Kong & 56.82 & 57.23 & 55.69 & 53.88 & 10 & 11 & 14 & 16 & $\mathrm{HI}$ & $\mathrm{HI}$ & $\mathrm{HI}$ & $\mathrm{HI}$ & SEAO & SEAO & SEAO & SEAO & 0.66 & 0.69 & 0.61 & 0.61 \\
\hline Switzerland & 64.78 & 68.30 & 66.28 & 67.69 & 1 & 1 & 1 & 1 & $\mathrm{HI}$ & $\mathrm{HI}$ & $\mathrm{HI}$ & $\mathrm{HI}$ & EUR & EUR & EUR & EUR & 0.95 & 1.01 & 0.94 & 0.95 \\
\hline Denmark & 57.52 & 57.70 & 58.45 & 58.70 & 8 & 10 & 8 & 6 & $\mathrm{HI}$ & $\mathrm{HI}$ & $\mathrm{HI}$ & $\mathrm{HI}$ & EUR & EUR & EUR & EUR & 0.76 & 0.75 & 0.74 & 0.71 \\
\hline Germany & 56.02 & 57.05 & 57.94 & 58.39 & 13 & 12 & 10 & 9 & $\mathrm{HI}$ & $\mathrm{HI}$ & $\mathrm{HI}$ & $\mathrm{HI}$ & EUR & EUR & EUR & EUR & 0.86 & 0.87 & 0.87 & 0.84 \\
\hline China & 46.57 & 47.47 & 50.57 & 52.54 & 29 & 29 & 25 & 22 & UM & UM & UM & UM & SEAO & SEAO & SEAO & SEAO & 1.03 & 0.96 & 0.90 & 0.94 \\
\hline Spain & 49.27 & 49.07 & 49.19 & 48.81 & 27 & 27 & 28 & 28 & $\mathrm{HI}$ & $\mathrm{HI}$ & $\mathrm{HI}$ & $\mathrm{HI}$ & EUR & EUR & EUR & EUR & 0.76 & 0.72 & 0.72 & 0.94 \\
\hline Norway & 55.59 & 53.80 & 52.01 & 53.14 & 14 & 20 & 22 & 19 & HI & HI & $\mathrm{HI}$ & $\mathrm{HI}$ & EUR & EUR & EUR & EUR & 0.78 & 0.73 & 0.68 & 0.66 \\
\hline Sweden & 62.29 & 62.42 & 63.57 & 63.82 & 3 & 3 & 2 & 2 & $\mathrm{HI}$ & HI & HI & $\mathrm{HI}$ & EUR & EUR & EUR & EUR & 0.85 & 0.86 & 0.86 & 0.83 \\
\hline
\end{tabular}

Note: World Bank Income Group Classification (July 2015): UM = upper-middle income; and $\mathrm{HI}=$ high income. Regions are based on the United Nations Classification: EUR = Europe; NAC $=$ Northern America; and SEAO = South East Asia, and Oceania.

This table depicts the overall GII score, which is the simple average of the input and output Sub-Index scores; the rank of selected countries in innovation; and the innovation efficiency ratio, which is the ratio of the output sub-index score over the input sub-index score. It shows how much innovation output a given country is getting for its inputs (Global Innovation Index, 2016). The top 25 places in the Global Innovation Indices (GII) are reserved by a 
stable set of high income countries that constantly lead in innovation. However, in the year 2016, a middle-income country (China) for the first time is among the top 25 due to the inclusion of new measures and indicators. Another major observation is that Switzerland remains at number 1 for six consecutive years. Sweden, the UK, and Switzerland are consistently ranked higher than the U.S.

\section{Research on Leadership in Eastern and Western Nations}

In order to illustrate the impact of leadership on innovation, researchers have considered various approaches and paradigms to examine how leadership encourages innovation. Several studies demonstrated that employees' innovative behavior highly relies on their interaction with others and on the environmental contextual factors in the organization (Axtell et. al., 2000; West \& Sacramento, 2012; Zhou \& Shalley, 2003). Of all the contextual factors that impact employees' work environment, leadership has been recommended as one of the critical factors for accomplishing individual and organizational effectiveness and innovation (Engelen, Schmidt, Strenger, \& Brettel, 2014; Mathisen, Einarsen \& Mykletun, 2012; McMahon \& Ford, 2013; Mumford, Connelly \& Gaddis, 2003; Wang, Rode, Shi, Luo, \& Chen, 2013; Yukl, 2008). Furthermore, the literature reveal that leadership studies are mainly quantitative investigations of the impact of existing theories of leadership, such as transformational leadership, leader-member exchange theory, empowering leadership, and authentic leadership. However, transformational leadership was one of the theories that was examined widely as an indicator/determinant of innovation and creativity (Cheung \& Wong, 2011; Jaffer, 2013; Lee, 2008; Qu, Jansen \& Shi, 2015; Sun, Zhang, Qi, \& Chen, 2012; To, Tse \& Ashkanasy, 2015; Wang \& Zhu, 2011). Numerous studies on organizational leadership indicated that organizational leadership is a crucial element for positive organizational outcomes to arise, and there is a direct association between leadership and organizational performance at individual, team, and collective levels (Avolio, Walumbwa \& Weber, 2009; Bass, 2008; Clark, Murphy \& Singer, 2014; Kaiser, Hogan \& Craig, 2008; Lussier \& Achua, 2013; McDermott, Kidney \& Flood, 2011; Sarros 2009; Yuk1, 2012). Leaders are significant factor that leverage and shape the organization's future through their tactics, decisions, and influences on others (Bass 2008; Kaiser, Hogan \& Craig, 2008). Hence, it can be said that leadership may be perceived as a multidimensional, interpersonal, and relational interaction between individuals in a particular setting. Somech's (2006) survey of 1,292 members of 136 primary care teams and their corresponding managers found that a participative leadership style is positively related to team reflection and, in turn, to team innovation. Another leadership model that shares some similarities with participative leadership and has been found relevant to creativity and innovation is empowering leadership. This emphasizes providing employees with autonomy and freedom and reducing bureaucratic obstructions (Ahearne, Mathieu \& Rapp, 2005; Babakus, Yavas, Karatepe, \&Avci, 2003; Forrester, 2000).

Research on ethical leadership has reported that there are significant benefits to an organization that encompasses it as well as the leader who applies it. Significantly, research on ethical leadership has offered that this leadership style is a powerful force that positively brings outstanding organizational outcomes, particularly with regard to employees' behaviors and performances (Brown \& Mitchell, 2010; Brown \& Trevino, 2014; De Hoogh\& Den 
Hartog, 2008; Den Hartog \& Belschak, 2012; Jordan, Brown, Trevino, \& Finkelstein, 2011; Mayer, Aquino, Greenbaum, \&Kuenzi, 2012; Piccolo, Greenbaum, Den Hartog, \&Folger, 2010). Among the positive outcomes of possessing ethical leadership: (a) higher perceptions of leadership effectiveness (Dion 2012; Eisenbeiss, 2012; Mayer et al., 2012; Schaubroeck et al., 2012); (b) developing and fostering an ethical climate (Caldwell, Hayes, Bernal, \& Karri, 2007; Grojean, Resick, Dickson, \& Smith, 2004; Mayer, Kuenzi \& Greenbaum, 2010); (c) motivating employees to exhibit organizational citizenship behaviors (Shin, 2012); and (d) generating organizational commitment among employees (De Cremer, Brebels\&Sedikides, 2008; Den Hartog \& Belschak, 2012; Neubert, Carlson, Kacmar, Roberts, \&Chonko, 2009). In addition, research shows that leadership behaviors that are empowering contribute to positive individual and organizational outcomes: the survey by Vecchio, Justin, and Pearce (2010) of a sample of 179 superior-subordinate suggested that empowering leadership is linked with higher employee level of performance and satisfaction. Other studies also indicated that providing autonomy enhances innovative behavior by influencing employees' cognitive processes (Krause, 2004) and self-determination (Forrester, 2000).

Ozaralli's (2015) study of 218 employees in the technology and service sector in Istanbul showed a positive association between empowering leadership and employees' creativity. Yoshida, Sendjaya, Hirst, and Cooper (2014) in a survey of 154 teams working in Chinese and Indonesian enterprises also found that servant leadership promotes employees' creativity and team innovation by encouraging identification with the leader. Another survey by Rego, Sousa, Marques, and Pina e Cunha (2012) found a positive association between authentic leadership and creativity and innovativeness, on manufacturing and service employees. Osborn and Marion (2009) empirically examined the influence of leadership style and innovation in American and Japanese research-intensive sectors, and surprisingly found that transformational leadership was significantly associated with lower innovation.

Pimpa and Moore's (2012) study with 134 participants from Thai public education organizations and 110 from the Australian public education sector indicated significantly different effective leadership styles in the two countries. In Thailand's public education sector, goal-oriented leadership was found to be effective, while in the Australian sector, leadership styles focusing on equality among organizational members that shaped a supportive and participating working environment. Another study by Lee, Scandura and Sharif (2014) delivered the role of culture in studying leadership across two cultures (USA and Korea). They found that the relationship between leader-member exchange and commitment to organizational change was higher in the US sample than in Korea due to the difference in power distance in the two nations. Rymer (2008) investigated leadership in Australia and conducted 30 interviews with Australian business leaders, suggesting that leadership in Australia is different from that in the USA and has unique qualities such as emotional togetherness, recognition and values, communication and strategic change.

Proposition 1: leadership competencies influence the ability to innovate in public sector organizations 


\section{Overcoming Barriers to Innovate}

There exist a considerable number of barriers that hinder a culture of innovation particularly in the public sector. Traditional public organizations are often ineffective and restrain endeavours that can promote innovation. Fostering innovation in the public sector requires different activities that defeat classic bureaucratic models (Vigoda-Gadot, Shoham, Schwabsky, \& Ruvio, 2008). These arguments were advocated in a series of works by Borins (1998, 2000a, 2000b, 2001). Unsurprisingly, bureaucracies often appear reluctant to change by adopting new ideas and embracing unconventional techniques in their processes. Therefore, public sector organizations are often criticized for their inability to foster and implement innovations; however, various bureaucracies of various types and cultures appear more conservative with working processes. Torugsa and Arundel (2016) noted that the more complex the innovation, the greater the number of barriers a workforce has to confront in its implementation. They concluded that government employees confront more obstacles for developing a complex innovation than for a simple innovation. In addition, complex innovations are difficult to implement in a highly centralized organization. Their findings also suggest that complex innovations are more valuable than simple innovations. Practically, they recommended that public sector employers can enhance a culture of complex innovations through (a) developing their management competencies; (b) avoiding barriers by recognizing sources for innovation; and (c) developing conditions that can motivate all individuals in the organization to innovate. However, this requires an incentive system as well as offering adequate resources to invest in innovations.

Lee, Hwang and Choi (2012) examined the contemporary open innovation practices in the public sector of leading countries (e.g., USA, Australia, and Singapore); their findings revealed three significant practices: government-led versus community-led open innovation, the lack of inside-out open innovation, and the need for developing an overarching strategic plan in citizen sourcing. The Australian Public Service Commission (APSC) (2016) noted that agencies report the following strategies are beneficial in fostering innovation: implementing strategic, digital, and/or innovation plans to foster an innovative culture within the agency; focusing on digital transformation and technology to create and improve processes; encouraging innovative ideas from all employees; providing opportunities for staff to participate in innovation forums, labs, and sessions; rewarding individuals for innovative ideas; and developing committees or councils to offer a coordinated approach to innovation.

Cocks (2009) proposed nine elements of success from Australia's winning organizations that are interconnected and fit together to operate effectively and help organizations accomplish their mission, vision, and objectives. However, Cocks urged that success is based on advanced implementation of all the following elements to deliver results (effective execution; perfect alignment; adapt rapidly; clear and fuzzy strategy; leadership, not leaders; looking out, looking in; the right people; manage the downside; and balance everything). However, Kinicki and Williams (2011, p. 319) noted "the problem with innovation is that there are too many challenges associated with it, which makes success unpredictable, although it is possible to establish cultural and other conditions that increase the likelihood of a payoff'. Fostering disruptive inn ovation in the public sector should go through three major 
components: (a) Focus: determine what needs to be achieved in the short and long-term; (b) Shape: specify how and where to begin disrupting; and (c) Grow: foster and cultivate the disruptive innovation (Eggers, Baker, Gonzalez, \& Vaughn, 2012). They also concluded that disruptive innovation processes can transform public services; however, this necessitates novel business models, new participants, new technologies, and the tendency to eliminate old ways of doing things or existing practices.

Proposition 2: Key barriers such as resistance to change have a negative influence on the ability to innovate in public sector organizations

\section{Creating Environments/Climates to Promote Innovation}

The development of a supportive climate for enhancing employees' innovative behavior and creativity is not an option. Tan, Smyrnios, and Xiong (2014) claimed that whenever employees 'feel good' about their organization's climate, they perform their tasks better and leaders can anticipate innovative behavior and creativity from them. As a caveat, when the organizational climate emphasizes reliability and efficiency and is not concerned with creativity and innovation, individuals may feel reluctant to take initiative even when they are offered some autonomy (Yukl, 2010). Bamel, Budhwar, and Bamel (2013) found that a large number of studies in organizational climate is based on empirical and quantitative research design, such as Von Treuer and McMurray (2012), who advocated a social constructionist (objectivist) approach, or Hassan and Rohrbaugh (2012), who supported a general psychological climate (subjectivist) perspective. Baer and Frese (2003) examined organizational climates to identify those climates that positively affected the relationship between process innovation and organizational performance. Baer and Frese examined 47 mid-sized German organizations and reviewed the relationship between process innovations, climates for initiative, psychological safety, and organizational performance. They found that there was a direct relationship between climate for initiative and psychological safety and organizational performance. They also reported that the consistent interactions between process innovations and organizational climate require systematic efforts to enhance climates for initiative and safety.

Proposition 3: Organizational climate has a positive influence on the ability to innovate in public sector organizations 


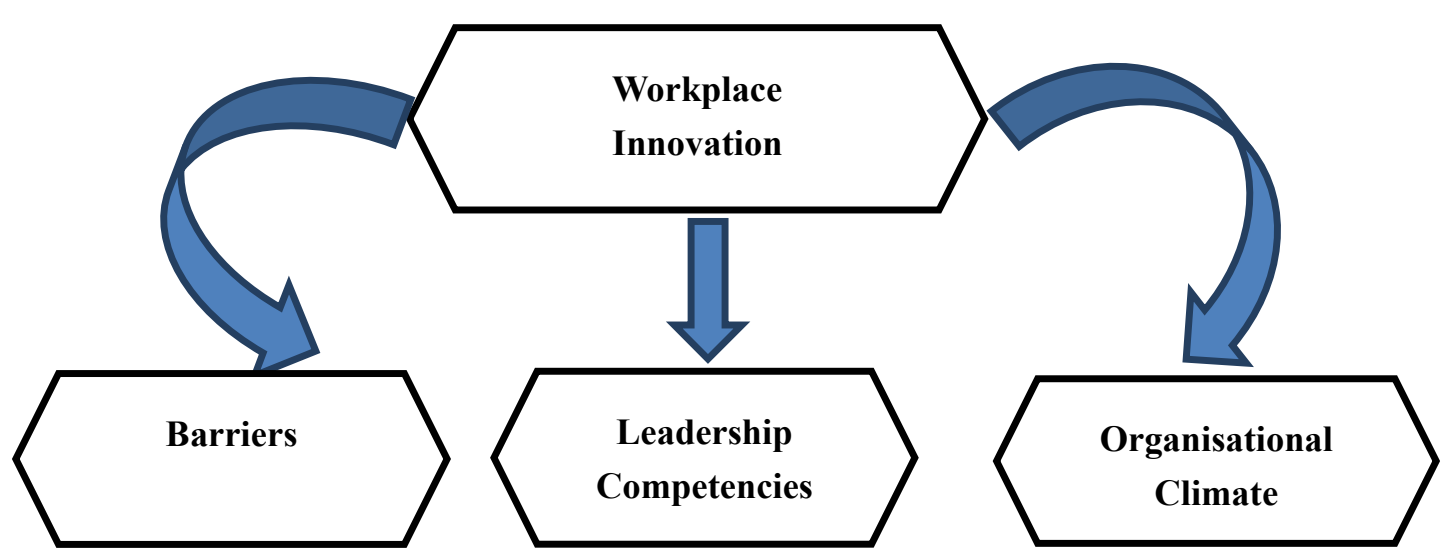

Figure 1. Proposed Conceptual Model of Workplace Innovation

Source: Author

\section{Conclusion}

Organizations are struggling to build capacity to be innovative for several reasons. Therefore, one major challenge for practitioners is to develop systems, processes, and climates that promote and demonstrate innovation and creativity. In other words, the development of a supportive climate for enhancing employees' innovative behavior and creativity is not an option. While much public sector research is centred on why the public sector should change and what changes should be made, little is known about how to encourage the whole systems towards having greater innovation capacity.

\section{References}

Ahearne, M., Mathieu, J., \& Rapp, A. (2005). To Empower or Not to Empower Your Sales Force? An Empirical Examination of the Influence of Leadership Empowerment Behavior on Customer Satisfaction and Performance. Journal of Applied Psychology, 90(5), 945-955. https://doi.org/10.1037/0021-9010.90.5.945

Australian Public Service Commission (2016).State of the Service Report 2015-2016. Retrieved http://www.apsc.gov.au/_data/assets/pdf_file/0008/89225/SoSR-2015-16.pdf, accessed March 19, 2017.

Avolio, B.J., Walumbwa, F.O., \& Weber, T.J. (2009). Leadership: Current Theories, Research, and Future Directions. Annual Review of Psychology, 60, 421-449. https://doi.org/10.1146/annurev.psych.60.110707.163621

Axtell, C.M., Holman, D.J., Unsworth, K.L., Wall, T.D., Waterson, P.E., \& Harrington, E. (2000). Shopfloor Innovation: Facilitating the Suggestion and Implementation of Ideas. Journal of Occupational \& Organizational Psychology, 73(3), 265-285. https://doi.org/10.1348/096317900167029

Babakus, E., Yavas, U., Karatepe, O.M., \&Avci, T. (2003). The Effect of Management 
Commitment to Service Quality on Employees' Affective and Performance Outcomes. Journal of the Academy of Marketing Science, 31(3), 272-286. https://doi.org/10.1177/0092070303031003005

Baer, M., \& Frese, M. (2003). Innovation is Not Enough: Climates for Initiative and Psychological Safety, Process Innovations, and Firm Performance. Journal of Organisational Behavior, 24(1), 45-68. https://doi.org/10.1002/job.179

Bakke, O., \& Nielsen, M.K. (2014). Public Sector Innovation: An Empirical Study on Managers in the Norwegian Public Sector. Master's Thesis. Norwegian University of Science and Technology. Department of Industrial Economics and Technology Management. Retrieved from http://www.diva-portal.org/smash/get/diva2:737985/FULLTEXT01.pdf, accessed September 10, 2014.

Bamel, U.K., Budhwar, P., \& Bamel, N. (2013). Revisiting Organisational Climate: Conceptualization, Interpretation and Application. Paper Presented to $3^{\text {rd }}$ Biennial Conference of the Indian Academy of Management (IAM), Indian Institute ofManagement, Ahmedabad (IIMA), 12-14 December, 2013. Retrieved from http://vslir.iima.ac.in:8080/xmlui/handle/11718/11533, accessed January 5, 2017.

Bartos, S. (2003). Creating and Sustaining Innovation. Australian Journal of Public Administration, 62(1), 9-14. https://doi.org/10.1111/1467-8500.00309

Bass, B.M. (2008). The Bass Handbook of Leadership: Theory, Research and Managerial Application ( $4^{\text {th }}$ ed.). The Free Press, New York, NY.

Borins, S. (1998). Innovation with Integrity. Washington, D.C., : Georgetown University Press.

Borins, S. (2000a). Loose Cannons and Rule Breakers, or Enterprising Leaders? Some Evidence about Innovative Managers. Public Administration Review, 60(6), 498-507. https://doi.org/10.1111/0033-3352.00113

Borins, S. (2000b). What Border? Public Management Innovation in the United States and Canada. Journal of Policy Analysis and Management, 19(1), 46-74. https://doi.org/10.1002/(SICI)1520-6688(200024)

Borins, S. (2001). The Challenge of Innovating in Government. The PricewaterhouseCoopers Endowment for The Business of Government. Retrieved from http://www.strategie-cdi.ro/spice/admin/UserFiles/File/CA\%20The\%20Challenge\%20of\%20i nnovating\%20in\%20government.pdf, accessed February 20, 2017.

Borins, S. (2001). Encouraging Innovation in the Public Sector. Journal of Intellectual Capital, 2(3), 310-319. https://doi.org/10.1108/14691930110400128

Brown, M.E., \& Mitchell, M.S. (2010). Ethical and Unethical Leadership: Exploring New Avenues for Future Research. Business Ethics Quarterly, 20(4), 583-616. Retrieved fromhttps://www.jstor.org/stable/25763039?seq=1\#page_scan_tab_contents, accessed March $5,2017$. 
Brown, M.E., \& Trevino, L.K. (2014). Do Role Models Matter? An Investigation of Role Modeling as an Antecedent of Perceived Ethical Leadership. Journal of Business Ethics, 122(4), 587-598. https://doi.org/10.1007/s10551-013-1769-0

Caldwell, C., \& Hayes, L.A., Bernal, P. \& Karri, R. (2007). Ethical Stewardship-Implications for Leadership and Trust. Journal of Business Ethics, 78(1-2), 153-164. https://doi.org/10.1007/s10551-006-9320-1

Chesbrough, H., Vanhaverbeke, W., Bakici, T., \& Lopez, H. (2011). Open Innovation and Public Policy in Europe. ESADE Business School and the Science Business Innovation Board AISBL. Science/Business Publishing Ltd.

Retrieved

from

http://www.sciencebusiness.net/Assets/27d0282a-3275-4f02-8a3c-b93c2815208c.pdf,accesse d September 10, 2014.

Cheung, M.F.Y., \& Wong, C-S. (2011). Transformational Leadership, Leader Support, and Employee Creativity. Leadership \& Organization Development Journal, 32(7), 656-672. https://doi.org/10.1108/01437731111169988

Clark, J.R., Murphy, C., \& Singer, S.J. (2014). When do Leaders Matter? Ownership, Governance and the Influence of CEOs on Firm Performance. The Leadership Quarterly, 25(2), 358-372. https://doi.org/10.1016/j.leaqua.2013.09.004

Cocks, G. (2009). High Performers Down Under: Lessons from Australia’s Winning

$\begin{array}{lllll}\text { Companies. Journal of } & \text { Business }\end{array}$ https://doi.org/10.1108/02756660910972613

De Cremer, D., Brebels, L., \& Sedikides, C. (2008). Being Uncertain about what? Procedural Fairness Effects as a Function of General Uncertainty and Belongingness Uncertainty. Journal of Experimental Social Psychology, 44(6), 1520-1525. https://doi.org/10.1016/j.jesp.2008.07.010

De Hoogh, A.H.B., \& Den Hartog, D.N. (2008). Ethical and Despotic Leadership, Relationships with Leader's Social Responsibility, Top Management Team Effectiveness and Subordinates' Optimism: A Multi-method Study. The Leadership Quarterly, 19(3), 297-311. https://doi.org/10.1016/j.leaqua.2008.03.002

Den Hartog, D.N., \& Belschak, F.D. (2012). Work Engagement and Machiavellianism in the Ethical Leadership Process. Journal of Business Ethics 107(1), 35-47. https://doi.org/10.1007/s10551-012-1296-4

Dion, M. (2012). Are Ethical Theories Relevant for Ethical Leadership?. Leadership \& Organization Development Journal, 33(1), 4-24. https://doi.org/10.1108/01437731211193098

Dumay, J., Rooney, J., \& Marini, L. (2013). An Intellectual Capital-Based Differentiation Theory of Innovation Practice.Journal of Intellectual Capital, 14(4), 608-633. https://doi.org/10.1108/JIC-02-2013-0024 
Eggers, W., Baker, L., Gonzalez, R., \& Vaughn, A. (2012). Disruptive Innovation: A New Model for Public Sector Services. Strategy and Leadership, 40(3), 17-24. https://doi.org/10.1108/10878571211221176

Eisenbeiss, S.A. (2012). Re-thinking Ethical Leadership: An Interdisciplinary Integrative Approach. The Leadership Quarterly, 23(5), 791-808. https://doi.org/10.1016/j.leaqua.2012.03.001

Engelen, A., Schmidt, S., Strenger, L., \& Brettel, M. (2014). Top Management's Transformational Leader Behaviors and Innovation Orientation: A Cross-Cultural Perspective in Eight Countries. Journal of international Management, 20(2), 124-136. https://doi.org/10.1016/j.intman.2013.04.003

Forrester, R. (2000). Empowerment: Rejuvenating a Potent Idea. The Academy of Management Executive, 14(3), 67-80. https://doi.org/10.1108/mbe.2002.26706baf.006

Grojean, M.W., Resick, C.J., Dickson, M.W., \& Smith, D.B. (2004). Leaders, Values, and Organizational Climate: Examining Leadership Strategies for Establishing an Organizational Climate Regarding Ethics. Journal of Business Ethics, 55(3), 223-241. https://doi.org/10.1007/s10551-004-1275-5

Hassan, S., \& Rohrbaugh, J. (2012). Variability in the Organisational Climate of Government Offices and Affective Organisational Commitment. Public Management Review, 14(5), 563-584. https://doi.org/10.1080/14719037.2011.642568

Jaffer, S. (2013). Harnessing Innovation in the $21^{\text {st }}$ Century: The Impact of Leadership Styles. $\mathrm{PhD}$ Thesis, George Washington University. Retrieved fromhttp://search.proquest.com/openview/18b56cad2b53a5605a5df95c7e825be5/1?pq-origsit $\mathrm{e}=\mathrm{gscholar} \& \mathrm{cbl}=18750 \&$ diss $=\mathrm{y}$, accessed March 5, 2017.

Jensen, B. (2010). Social Innovation in Public Sector Strategies Addressing Endangered Children: Approaching the Basis for Social Innovation with an Organizational Learning Theory. Paper Presented at the 2008 OLKC Conference Learning to Innovate: Innovating to Learn, Northeastern University Boston, Ma., USA, June 3-6, 2010. Retrieved from http://www2.warwick.ac.uk/fac/soc/wbs/conf/olkc/archive/olkc5/papers/207_bente_full_pape r_312_social_innovation_in_public_sector_strategies_addressing_endangered_children.pdf, accessed September 10, 2014.

Jordan, J., Brown, M.E., Trevino, L.K., \& Finkelstein, S. (2011). Someone to look up to: Executive-follower Ethical Reasoning and Perceptions of Ethical Leadership. Journal of Management, 39(3), 660-683. https://doi.org/10.1177/0149206311398136

Kaiser, R.B., Hogan, R., \& Craig, S.B. (2008). Leadership and the Fate of Organizations. American Psychologist, 63(2), 96-110. https://doi.org/10.1037/0003-066X.63.2.96

Kinicki, A., \& Williams, B.K. (2011). Management: A Practical Introduction (5 ${ }^{\text {th }}$ ed.). McGraw-Hill, Inc.

Krause, D.E. (2004). Influence-based Leadership as a Determinant of the Inclination to 
Innovate and of Innovation-related Behaviors: An Empirical Investigation. The Leadership Quarterly, 15(1), 79-102. https://doi.org/10.1016/j.leaqua.2003.12.006

Lee, J. (2008). Effects of Leadership and Leader-Member Exchange on Innovativeness. $\begin{array}{llll}\text { Journal of } \quad \text { Managerial 23(6), } & \text { 670-687. }\end{array}$ https://doi.org/10.1108/02683940810894747

Lee, S.M., Hwang, T., \& Choi, D. (2012). Open Innovation in the Public Sector of Leading Countries. Management Decision, 147-162. https://doi.org/10.1108/00251741211194921

Lee, K., Scandura, T.A., \& Sharif, M.M. (2014). Cultures Have Consequences: A Configural Approach to Leadership across Two Cultures. The Leadership Quarterly, 25(4), 692-710. https://doi.org/10.1016/j.leaqua.2014.03.003

Lekhi, R. (2007). Public Service Innovation.A Research Report for the Work Foundation's Knowledge Economy. Research Republic LLP: Manchester. Retrieved from http://www.theworkfoundation.com/downloadpublication/report/70_70_psi2.pdf, accessed September 10, 2014.

Luke, B., Verreynne, M.L., \& Kearins, K. (2010). Innovative and Entrepreneurial Activity in the Public Sector: The Changing Face of Public Sector Institutions. Innovation: Management, Policy and Practice, 12(2), 138-153. https://doi.org/10.5172/im12.2.138

Lussier, R.N., \& Achua, C.F. (2013). Leadership: Theory, Application \& Skill Development $\left(5^{\text {th }}\right.$ ed.). South Western Cengage Learning, Mason, $\mathrm{OH}$.

Mathisen, G.E., Einarsen, S., \& Mykletun, R. (2012). Creative Leaders Promote Creative Organizations. International Journal of Manpower, 33(4), 367-382. https://doi.org/10.1108/01437721211243741

Mayer, D.M., Aquino, K., Greenbaum, R.L., \& Kuenzi, M. (2012). Who Displays Ethical Leadership, and Why Does It Matter? An Examination of Antecedents and Consequences of Ethical Leadership. Academy of Management Journal, 55(1), 151-171. https://doi.org/10.5465/amj.2008.0276

Mayer, D.M., Kuenzi, M., \& Greenbaum, R.L. (2010). Examining the Link between Ethical Leadership and Employee Misconduct: The Mediating Role of Ethical Climate. Journal of Business Ethics, 95(1), 7-16. https://doi.org/10.1007/s10551-011-0794-0

McDermott, A., Kidney, R., \& Flood, P. (2011). Understanding Leader Development: Learning from Leaders. Leadership \& Organization Development Journal, 32(4), 358-378. https://doi.org/10.1108/01437731111134643

McMahon, S.R., \& Ford, C.M. (2013). Heuristic Transfer in the Relationship Between Leadership and Employee Creativity. Journal of Leadership \& Organizational Studies, 20(1), 69-83. https://doi.org/10.1177/1548051812465894

Mumford, M.D., Connelly, S., \& Gaddis, B. (2003). How Creative Leaders Think: 
Experimental Findings and Cases.The Leadership Quarterly, 14(4-5), 411-432. https://doi.org/1048984303000456

Neubert, M.J., Carlson, D.S., Kacmar, K.M., Roberts, J.A., \& Chonko, L.B. (2009). The Virtuous Influence of Ethical Leadership Behavior: Evidence from the Field. Journalof Business Ethics, 90(2), 157-170. https://doi.org/10.1007/s10551-009-0037-9

O’Byrne, L., Miller, M., Douse, C., Venkatesh, R.., \& Kapucu, N. (2014). Social Innovation in the Public Sector: The Case of Seoul Metropolitan Government. Journal ofEconomic and Social Studies, 4(1), 51-68. https://doi.org/10.14706/jecoss11414

Osborn, R.N., \& Marion, R. (2009). Contextual Leadership, Transformational Leadership and the Performance of International Innovation Seeking Alliances. The Leadership Quarterly, 20(2), 191-206. https://doi.org/10.1016/j.leaqua.2009.01.010

Ozaralli, N. (2015). Linking Empowering Leader to Creativity: The Moderating Role Of Psychological (Felt) Empowerment. Procedia-Social and Behavioral Sciences, 181(11), 366-376. https://doi.org/10.1016/j.sbspro.2015.04.899

Piccolo, R.F., Greenbaum, R., Den Hartog, D.N., \& Folger, R. (2010). The Relationship Between Ethical Leadership and Core Job Characteristics. Journal of Organizational Behavior, 31(2-3), 259-278. https://doi.org/10.1002/job.627

Pimpa, N., \& Moore, T. (2012). Leadership Styles: A Study of Australian and Thai Public Sectors. Asian Academy of Management Journal, 17(2), 21-37. Retrieved from http://web.usm.my/aamj/17.2.2012/AAMJ_17.2.2.pdf, accessed January 17, 2017.

Potts, J., \& Kastelle, T. (2010). Public Sector Innovation Research: What's Next?. Innovation, Management, Policy and Practice, 12(2), 122-137. https://doi.org/10.5172/im12.2.122

Qu, R., Janssen, O., \& Shi, K. (2015). Transformational Leadership and Follower Creativity: The Mediating Role of Follower Relational Identification and the Moderating Role of Leader Creativity Expectations. The Leadership Quarterly, 26(2), 286-299. https://doi.org/10.1016/j.leaqua.2014.12.004

Rego, A., Sousa, F., Marques, C., \&Pina e Cunha, M. (2012). Authentic Leadership Promoting Employees' Psychological Capital and Creativity. Journal of Business Research, 65(3), 429-437. https://doi.org/10.1016/j.jbusres.2011.10.003

Rymer, C.S. (2008). Leadership in Australia: How Different Are We?, PhD Thesis, Southern Cross University. Retrieved from http://epubs.scu.edu.au/cgi/viewcontent.cgi?article=1117\&context=theses, accessed March 12, 2017.

Sarros, J.C. (2009). Contemporary Perspectives on Leadership: Focus and Meaning for Ambiguous Times ( $1^{\text {st }}$ ed.). Tilde University Press, Melbourne.

Schaubroeck, J.M., Hannah, S.T., Avolio, B.J., Kozlowski, S.W.J., Lord, R.G., Trevino, L.K., Dimotakis, N., \& Peng, A.C. (2012). Embedding Ethical Leadership within and Across 
Organization Levels. Academy of Management Journal, 55(5), 1053-1078. https://doi.org/10.5465/amj.2011.0064

Shin, Y. (2012). CEO Ethical Leadership, Ethical Climate, Climate Strength, and Collective Organizational Citizenship Behavior. Journal of Business Ethics, 108(3), 299-312. https://doi.org/10.1007/s10551-011-1091-7

Somech, A. (2006). The Effects of Leadership Style and Team Process on Performance and Innovation in Functionally Heterogeneous Teams. Journal of Management, 32(1), 132-157. https://doi.org/10.1177/0149206305277799

Stewart-Weeks, M., \&Kastelle, T. (2015). Research and Evaluation: Innovation in the Public Sector. Australian Journal of Public Administration, 74(1), 63-72. https://doi.org/10.1111/1467-8500.12129

Sun, L.Y., Zhang, Z., Qi,J., \& Chen, Z.X. (2012). Empowerment and Creativity: A Cross-Level Investigation.The Leadership Quarterly, 23(1), 55-65. https://doi.org/10.1016/j.leaqua.2011.11.005

Tan, C.S.L., Smyrnios, K.X., \&Xiong, L. (2014). What Drives Learning Orientation in Fast Growth SMEs? International Journal of Entrepreneurial Behaviour\& Research, 20(4), 324-350. https://doi.org/10.1108/IJEBR-02-2013-0032

The Top 25 Global Innovators: Government (2016). Reuters News: Thomson Reuters IP \& Science. Available at http://images.info.science.thomsonreuters.biz/Web/ThomsonReutersScience/\%7B6b434462-d f76-451d-a9f9-b38cba4aafa2\%7D_tr-top25-govt-innovators.pdf

To, M.L., Tse, H.H.M., \&Ashkanasy, N.M. (2015). A Multilevel Model of Transformational Leader, Affect, and Creative Process Behavior in Work Teams.The Leadership Quarterly,26(4), 543-556. https://doi.org/10.1016/j.leaqua.2015.05.005

Torugsa, N.A., \& Arundel, A. (2016). Complexity of Innovation in the Public Sector: A Workgroup-Level Analysis of Related Factors and Outcomes. Public Management Review, 18(3), 392-416. https://doi.org/10.1080/14719037.2014.984626.

Vecchio, R.P., Justin, J.E., \& Pearce, C.L. (2010). Empowering Leadership: An Examination of Mediating Mechanisms within a Hierarchical Structure.The Leadership Quarterly, 21(3), 530-542. https://doi.org/10.1016/j.leaqua.2010.03.014

Vigoda-Gadot, E., Shoham, A., Schwabsky, N., \&Ruvio, A. (2008). Public Sector Innovation for the Managerial and the Post-Managerial Era: Promises and Realities in A Globalizing Public Administration. International Public Management Journal,8(1), 57-81. https://doi.org/10.1.1.318.8067

Von Treuer, K., \& McMurray, A.J. (2012). The Role of Organisational Climate Factors in Facilitating Workplace Innovation. International Journal of Entrepreneurship andInnovation Management, 15(4), 292-309. Retrieved From http://www.inderscienceonline.com/doi/abs/10.1504/IJEIM.2012.048078?journalCode=ijeim, 
accessed January 28, 2017.

Wang, P., \& Zhu, W. (2011). Mediating Role of Creative Identity in the Influence of Transformational Leadership on Creativity: Is there a Multilevel Effect?. Journal of $\begin{array}{lllll}\text { Leadership } \quad \& \quad \text { Organizational } & \text { Studies, } & 18(1),\end{array}$ https://doi.org/10.1177/1548051810368549

Wang, P., Rode, J.C., Shi, K., Luo, Z., \& Chen, W. (2013). A Workgroup Climate Perspective on the Relationships among Transformational Leadership, Workgroup Diversity, and Employee Creativity. Group \& Organization Management, 38(3), 334-360. https://doi.org/10.1177/1059601113488163

West, M., \& Sacramento, C. (2012). Creativity and Innovation: The Role of Team And Organizational Climate, in MD Mumford (ed.). Handbook of OrganizationalCreativity, Academic Press, London, 359-385.

Wu, J., Ma, L., \& Yang, Y. (2013). Innovation in the Chinese Public Sector: Typology and Distribution. Public Administration, 347-365. https://doi.org/10.1111/j.1467-9299.2011.02010.x

Yoshida, D.T., Sendjaya, S., Hirst, G., \& Cooper, B. (2014). Does Servant Leadership Foster Creativity and Innovation? A Multi-Level Mediation Study of Identification and Prototypicality. Journal of Business Research, 67(7), 1395-1404. https://doi.org/10.1016/j.jbusres.2013.08.013

Yukl, G.A. (2008). How Leaders Influence Organizational Effectiveness. The Leadership Quarterly, 19(6), 708-722. https://doi.org/10.1016/j.leaqua.2008.09.008

Yukl, G.A. (2010). Leadership in Organizations (7 $7^{\text {th }}$ ed.). Prentice Hall, Upper Saddle River, NJ.

Yuk1, G.A. (2012). Leadership in Organizations ( $8^{\text {th }}$ ed.). Pearson Education, Limited.

Zhou, J., \& Shalley, C.E. (2003). Research on Employee Creativity: A Critical Review and Proposal for Future Research Directions, in (ed.). Research in Personnel and Human Resources Management (Research in Personnel and Human Resources Management22, Emerald Group Publishing Limited, 165-217. Retrieved from http://www.emeraldinsight.com/doi/pdfplus/10.1016/S0742-7301\%2803\%2922004-1, accessed March 5, 2017. 